University of Nebraska - Lincoln

DigitalCommons@University of Nebraska - Lincoln

1990

\title{
The Generalizability of the Hidden Investment Hypothesis in Leading Japanese Corporations
}

\author{
Mitsuru Wakabayashi \\ Nagoya University \\ George Graen \\ University of Cincinnati \\ Mary Uhl-Bien \\ University of Nebraska-Lincoln, mbien2@unl.edu
}

Follow this and additional works at: https://digitalcommons.unl.edu/managementfacpub

Part of the Management Sciences and Quantitative Methods Commons

Wakabayashi, Mitsuru; Graen, George; and Uhl-Bien, Mary, "The Generalizability of the Hidden Investment Hypothesis in Leading Japanese Corporations" (1990). Management Department Faculty Publications. 41.

https://digitalcommons.unl.edu/managementfacpub/41

This Article is brought to you for free and open access by the Management Department at DigitalCommons@University of Nebraska - Lincoln. It has been accepted for inclusion in Management Department Faculty Publications by an authorized administrator of DigitalCommons@University of Nebraska - Lincoln. 


\title{
The Generalizability of the Hidden Investment Hypothesis in Leading Japanese Corporations
}

\author{
Mitsuru Wakabayashi \\ Nagoya University \\ George Graen \& Mary Uhl-Bien \\ University of Cincinnati
}

Corresponding author - George Graen, Center for International Competitiveness Studies, ML 165, University of Cincinnati, Cincinnati, Ohio 45221.

\begin{abstract}
The present study tests the generalizability of the hidden investment hypothesis (Wakabayashi, Graen, Graen, \& Graen, 1988) for Japanese management systems. The hidden investment hypothesis was derived from a 13-year longitudinal study of the career progress of a cohort of 85 college graduates who joined a single Japanese company in the same year, and states that the higher the quality of the vertical exchange relationship between a manager and supervisor, the greater the career progress of that manager. To test for the generalizability of the hidden investment hypothesis, 1,075 line managers at four different hierarchical levels were sampled from five of the leading corporations in Japan. Hierarchical regression and path analysis showed that both vertical exchange quality and hierarchical level contributed uniquely to investments in managers' careers after the contributions of company, age, tenure, education, technical specialty, and intrafirm mobility were controlled. The contributions of these control variables were estimated and a summary path diagram is presented. Implications of these findings for our understanding of Japanese management development are discussed.
\end{abstract}

The authors would like to thank Joan Graen, Mike Graen, Marty Graen, and M. Sano for their research assistance, and the Fulbright Commission, Nagoya University, and the University of Cincinnati for partial support on this project. 


\section{Introduction}

In contrast to Western management systems, Japanese systems have traditionally been recognized for their practice of "lifetime employment," in which tenured employees are ensured that they will be able to progress in their careers within the management system of the organization which hires them directly out of college (Yoshino, 1968; Ouchi \& Johnson, 1979; Abegglen \& Stalk, 1985; Johnson, 1989). Because of this, it is often believed that promotion in a Japanese organization occurs in a "lockstep" fashion-everyone is promoted at roughly the same point in their careers through the various levels in the organization, until the "cohort" of managers reaches the executive level. At this point, when the advancement opportunities become limited, the most promising individuals are identified to enter the executive suite (Takagi, 1985). The remaining managers of the cohort are then promoted out of the organization. Thus, according to this model, career progress is similar for all managers in the organization until the cohort of managers nears the end of their careers, at which point the identification of those who will progress to the executive suite is determined.

Recently, however, the validity of this model of the Japanese career development system has been challenged by Wakabayashi, Graen, and colleagues (Wakabayashi et al., 1988; Graen, Wakabayashi, Graen, \& Graen, 1990). These authors have provided evidence that the "lock-step" portrayal of Japanese career progress may not be accurate. Instead, they suggest that managers in the Japanese system, similar to managers in the Western system, experience differentiation in their career progress throughout their careers, through a process of "hidden investment." According to hidden investment, the managers who will vie for the executive suite are identified early in their careers and prepared for their entry to the executive suite through "hidden investments" which occur throughout their careers.

Support for the hidden investment model was provided by a longitudinal investigation of Japanese line managers from their entry into an organization through their progression into middle management (Wakabayashi \& Graen, 1984). In this study, the hidden investment model was found to predict career progress of the Japanese line managers over the 13 years in which they were followed (Wakabayashi et al., 1988). Moreover, in a comparison of the hidden investment model to other competing models, the hidden investment model was found to be more predictive of career progress in Japanese management than the assessment center model (Bray \& Grant, 1986; Bray, Campbell, \& Grant, 1974) and the organizational commitment model (Porter, Crampton, \& Smith, 1976). 
Despite the support for the hidden investment model in the longitudinal investigation, however, it is still unclear whether the hidden investment hypothesis established in the model is generalizable to other leading Japanese corporations. Thus, the purpose of the present study is to further investigate the hidden investment model for Japanese career progress. The present study tests the generalizability of the hidden investment hypothesis across a sample of 1075 line managers in five leading Japanese manufacturing and service organizations. With the use of this sample, it is possible to determine whether the support for the hidden investment model which was provided by the homogeneous cohort investigated in the longitudinal study will also be provided by a more heterogeneous cross-section of Japanese line managers.

In the following paragraphs, Japanese management development systems will be discussed in terms of both the traditional view of Japanese career progress and from the perspective of the hidden investment approach for career development. The test for the generalizability of the hidden investment hypothesis, and the implications of the findings, will then be presented.

\section{Japanese Career Progress}

According to the traditional view of the Japanese career development system, the Japanese career begins with the hiring of new college graduates from the leading universities in Japan. These college graduates are recruited by the Japanese corporations, indoctrinated in a 2-3 month Kenshu camp, and then placed in entry level positions. They are expected to move up the authority hierarchies through job rotation, on-the-job education, and team management as a cohort until they reach the executive suite (Johnson, 1989). At this point, the most promising will be tested intensively over a period of 3-4 years to determine who will become executives. Those who adequately complete this testing process stay with the company, and can look forward to the status, challenge, influence, and the material and social rewards bestowed on the most valued contributors to the corporation. The others can expect a comfortable position for a short time, and early retirement. Since early retirement is not an attractive option for most Japanese managers, however, the competition to reach the executive suite can be fierce.

\section{Hidden Investment Model}

In contrast to this model, the hidden investment model developed by Wakabayashi and Graen (Wakabayashi et al., 1988; Graen et al., 1990) sug- 
gests that the identification and development of future Japanese executives occurs not only when the line managers reach the executive suite, but also throughout their careers. In a pioneering investigation spanning over 13 years, Wakabayashi, Graen, and colleagues (Wakabayashi, 1980; Wakabayashi \& Graen, 1984; Wakabayashi, Minami, Hashimoto, Sano, Graen, \& Novak, 1980; Wakabayashi et al., 1988; Graen et al., 1990) investigated for the first time the management progress of Japanese managers from their entry into a Japanese organization through their progression into middle management. In their studies, they documented career mobility among a group of 85 male college graduates with similar backgrounds entering a leading Japanese corporation at the same time. By following these young managers throughout the 13-year period, it was found that the best predictor of career progress in this organization is the "hidden investment" model (Wakabayashi et al., 1988; Graen et al., 1990).

According to the hidden investment model, those managers who are involved in high-quality exchange relationships with their supervisors early in their careers will advance more rapidly and to higher organizational levels than those managers who are not involved in these high-quality relationships with their supervisors. This enhanced career advancement occurs because the subordinates in the higher quality exchange relationships receive greater investments in their career development from their supervisors than those in lower quality exchange relationships. As part of this process, the managers with more promising promotability potential are recognized by the organization and the supervisor, and these managers receive increased investment in their careers from the organization through the supervisor. Thus, through the high-quality relationships, the supervisors invest more of their own valuable resources in the careers of these selected subordinates.

Moreover, this investment is not a formalized, "public face" process, but rather a more "hidden face" process which occurs between the manager and the subordinate (Zalesny \& Graen, 1987; Graen, 1989). Hence, although it appears on the surface that the managers are treated alike, differentiation between the selected and the non-selected managers is occurring through the hidden investments. As a result of the career investment, the selected subordinates are better prepared to handle the responsibilities which come with promotions into higher management ranks.

Hidden investments may take many forms. Graen (1989) has identified the key resources which bosses may provide to their subordinates as investments in the career progress of the subordinates. These investment behaviors include paying attention to the subordinate, providing the subordinate with inside information about the organization, giving the subordinate influence and authority in the organization, offering the subordinate latitude in the performance of his/her job, providing the subordinate with access to departmental resources, and allowing the sub- 
ordinate to participate in critical assignments. On a larger scale, an organization which is investing in the career of an employee will do so by ensuring that the manager's potential for growth in the organization is fully utilized. Thus, company investment in a manager's career includes ensuring that there are a variety of career opportunities available to the employee, that the supervisor is interested in the career progress of the employee and is demonstrating investment behaviors in that subordinate, and that the investment is perceived as valuable and fair to the employee, so that the employee will continue to be committed to career growth within the organization (Graen, 1989; Wakabayashi \& Graen, 1988).

In addition to the investments by the organization, hidden investments may include self-investment activities by the professionals themselves. According to the vertical exchange model (Graen \& Cashman, 1975; Liden \& Graen, 1980; Graen \& Scandura, 1987), when subordinates become involved in high vertical exchange relationships they take on added responsibilities, responsibilities which they are not required to perform since they are outside of their formal job description. By agreeing to grow out of their jobs through the acceptance of additional responsibilities, the subordinates are essentially engaging in self-investment behaviors (Graen, 1989; Graen \& Wakabayashi, 1989). These subordinates are becoming proactive in their career progress by working to develop high-quality relationships with their supervisors which will allow them to obtain additional resources, and thus better prepare them for advancement in their careers. The self-investment activities which may be used by an individual to advance in his/her career include: growing out of one's job by taking on added responsibilities, relationship building, taking risks, demonstrating initiative, forming insider networks, searching for new opportunities for self-improvement, etc. (Graen, 1989). Hence, by developing high-quality relationships with the supervisor through the use of self-investment behaviors, developing managers may gain greater access to organizational resources which are critical to their career development. In terms of the hidden investment model, therefore, self-investment behaviors by individuals are also influential in career progress.

Thus, the hidden investment hypothesis states that those managers who are involved in high-quality exchange relationships with their immediate supervisors will advance more rapidly and to higher managerial levels than those managers who are not involved in high-quality relationships with their supervisors. This advanced career progress occurs because the developing managers are able to gain more valuable investment in their careers by the organization and through their supervisors, while at the same time investing more in their own careers. The career investment bestowed by the supervisors on the high-quality managers, as well as the self-investment behaviors of these managers, better prepares them for advancement into higher level management ranks. In terms of 
the Japanese management system, the hidden investment hypothesis suggests that the differentiation between the "best of the best" who will make it to the executive suite and those who will not begins earlier in the career development process than previously thought.

\section{Hypotheses}

Based on the assumptions of the hidden investment hypothesis, several hypotheses for the present investigation may be proposed. Before these hypotheses are stated, however, it is necessary to address the issue of how the present study was conducted. Because of the infeasibility of conducting longitudinal investigations of large numbers of Japanese managers throughout their careers, the present study will use a crosssectional design. The managers to be studied are more representative of the Japanese salaryman than the longitudinal sample, since they include a larger number of managers (1075 respondents), at various managerial levels, from both manufacturing and service industries. Thus, the present sample, in contrast to the previously conducted longitudinal investigation of a homogeneous cohort, will allow us to test whether the hidden investment hypothesis will be supported in a sample which encompasses a large cross-section of Japanese managers, who vary in terms of age, education (level and type), tenure in company, mobility, organizational level (status), and company (manufacturing vs. service).

Moreover, since the design is not longitudinal, it is necessary to use a surrogate measure of career progress. The positive relationship between career investments and career progress has already been established in the Japanese management progress study (Wakabayashi \& Graen, 1984; Wakabayashi et al., 1988). In terms of this relationship, the hidden investment hypothesis states that it is the increased investment which the developing managers receive from the high-quality leadermember relationship which allows them to advance more successfully in their career. In other words, the predictive relationship between vertical exchange and career progress is instrumented by hidden investments. Thus, since hidden investments bestowed by the company and by the managers themselves are said to be indicative of career progress, hidden investments in the line managers will be used to assess the effect of the leadership relationship on the career progress of the 1075 Japanese line managers.

The hypotheses which will be tested in the present study are the following: (1) controlling for relevant background variables, vertical exchange will demonstrate a positive contribution to hidden investments in members' careers, and (2) controlling for relevant background variables, 
vertical exchange will demonstrate positive contributions to investments in members' careers at each hierarchical level from management trainee to middle manager. These hypotheses test for the generalizability of the hidden hypothesis to the present sample. Hidden investments will be examined in terms of company investment and self-investment. Company investment is a more general measure of investments, which includes both supervisor and organizational investments, and self-investment includes those behaviors which the managers use to invest in their own career progress.

\section{Method}

\section{Site and Sample}

Five of the leading corporations in Japan were sampled for this study. Three of the corporations were manufacturing firms and two were in service industries. Within the companies, data were collected from 1,075 line managers at various stages in their career development: 261 management trainees, 417 lower-level managers, 146 lower-middle managers, and 251 middle managers. The response rate was $78.2 \%$.

\section{Design of the Study}

The present study uses a cross-sectional design to test for the generalizability of the hidden investment hypothesis while controlling for the contribution of relevant background variables. As mentioned earlier, the background variables which will be examined include company, age, tenure, education, engineer mobility, and status. Thus, to control for the background variables, all hypotheses will be tested after the contributions of these variables have been extracted.

\section{Measures}

Predictor Measures. To measure the quality of the relationship between the line managers and their supervisors, the vertical exchange scale will be used (Wakabayashi et al., 1988). This measure, developed by Graen and colleagues (Dansereau, Graen, \& Haga, 1975; Graen, 1976; Wakabayashi et al., 1980; Wakabayashi \& Graen, 1984; Graen et al., 1990), measures the quality of the leadership relationship by assessing the effectiveness of the working relationship, and the dependability, helpfulness, and trust attributed to this relationship. Moreover, vertical exchange was 
found to be predictive of career development outcomes in the 13-year follow-up investigation of the Japanese Management Progress Study. In the present study, the 14-item vertical exchange instrument was employed (Cronbach's alpha $=.89$ ).

In addition to the vertical exchange scale, a set of background factors which may influence the hidden investment process were identified and measured. These background factors will be examined in the analyses to determine their effect on the hypothesized relationships. The background variables include: (1) company (manufacturing vs. others), (2) age, (3) tenure (years of service in the company), (4) education (seven ranks from compulsory to graduate levels), (5) engineer (engineering degree vs. others), (6) mobility (frequency of intrafirm job change), and (7) status (four ranks from managerial trainee to section manager).

Criterion Measures. To test the hidden investment hypotheses, two measures of hidden investment were assessed: (1) company investment, and (2) self-investment. Company investment consists of ten 5point items, including company's utilization of a manager's potential for growth, fairness of the investment, value of the investment, variety of career opportunities, career relevance of the investment, supervisor's interest in a manager's career progress, and overall assessment of the company's career investment. The Cronbach's alpha for this measure was 82 . Self-investment consists of 195 -point items. These items asked how frequently the manager engaged in role-making activities such as working to get one's immediate supervisor promoted and to improve one's leadership relationship with the supervisor, actively seeking out new opportunities for self-improvement, striving to add value to assignments, demonstrating initiative, taking risks, doing extra work, and generally attempting to make one's supervisor's unit more effective by growing out of one's present job. The Cronbach's alpha for this measure is .92.

\section{Analysis}

To test the hypotheses, several analytical techniques were employed. First, a correlational analysis was conducted to examine the relationships between the background variables and the vertical exchange measure. Second, a special regression analysis was needed to examine the independent contribution of the quality of vertical exchange to hidden investments. For this purpose, the contributions of background variables were partialled out and the unique effect of vertical exchange was calculated by using a method of hierarchical regression analyses (Cohen \& Cohen, 1975; Katerberg \& Hom, 1981; Wakabayashi \& Graen, 1984; Wakabayashi et al., 1988). The seven background variables entered the regression equation first as a set, and a squared multiple correlation coefficient $\left(R_{1}^{2}\right)$ was 
Table I. Correlation Coefficients among Background Measures and Vertical Exchange for Japanese Managers

\begin{tabular}{lrrrrrrrr}
\hline & 1 & 2 & 3 & 4 & 5 & 6 & 7 & 8 \\
\hline 1. Company & - & & & & & & & \\
2. Age & -.32 & - & & & & & & \\
3. Tenure & -.42 & .89 & - & & & & & \\
4. Education & .32 & -.42 & -.60 & - & & & & \\
5. Engineer & .31 & -.31 & -.41 & .63 & - & & & \\
6. Mobility & -.11 & .30 & .30 & -.07 & .27 & - & & \\
7. Status & -.21 & .56 & .46 & .01 & -.11 & .27 & - & \\
8. Vertical exchange & -.04 & .14 & .07 & .08 & .02 & -.01 & .20 & \\
\hline
\end{tabular}

Correlation $\geq .06 ; p \leq .025 ; N=1075$.

computed. Next the vertical exchange scale was introduced and $R_{2}^{2}$ was computed. The unique vertical exchange effect was identified in terms of a difference between the two $R^{2}$ s. The results of the regression analyses for the vertical exchange measure were then examined in terms of the two dependent variables to determine whether they were consistent across hierarchical levels, i.e., status levels. Finally, path analyses were run to clarify empirical relationships (Land, 1969).

\section{Results}

The results of the correlational analysis are presented in Table I. The correlations between vertical exchange and the background variables indicate that vertical exchange is not highly correlated with the background variables. In addition, examination of the correlations between the background variables with each other provides some insight into the characteristics of the sample. Specifically, it appears that: (1) significant differences between manufacturing and nonmanufacturing companies existed on all background variables, (2) higher degree holders tend to be younger, with less tenure and with an engineering background, and (3) higher level managers tend to be older, with more tenure and more intrafirm mobility.

Table II shows the results of the hierarchical regression analyses. In the first step of the regression analyses, the background variables are entered without vertical exchange. The results of this analysis are mixed: (1) company contributes negatively to the dependent variables, indicating that managers in manufacturing companies are at a disadvantage in their career investment activities compared to those in service companies, particularly in terms of company investment, (2) education and mobility appeared to contribute positively to the self-investment activities of the 


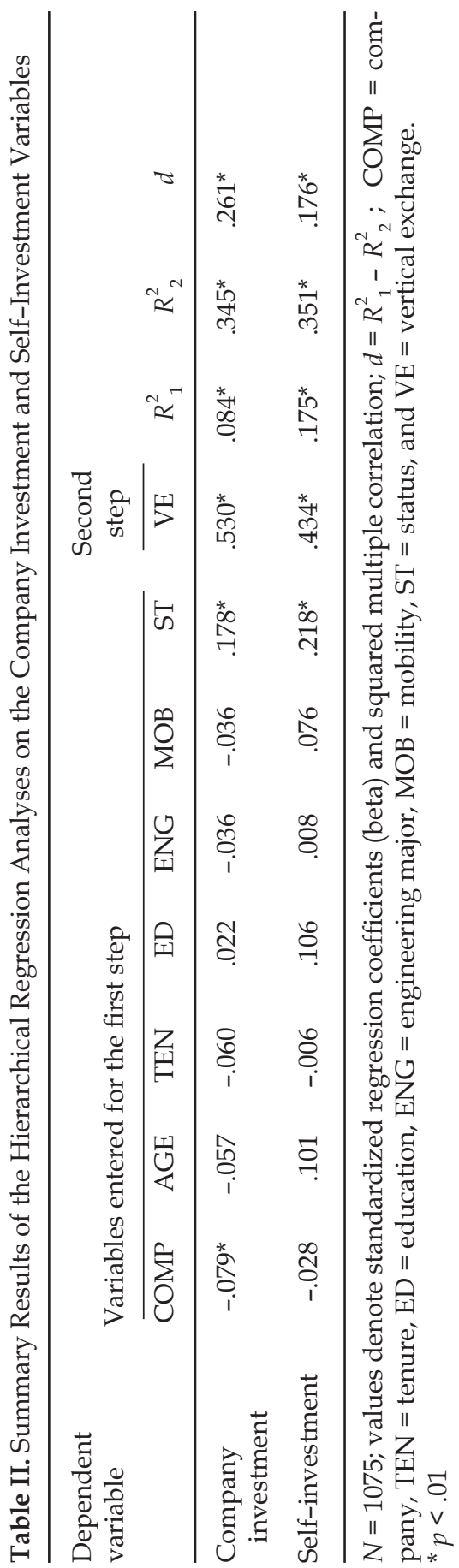




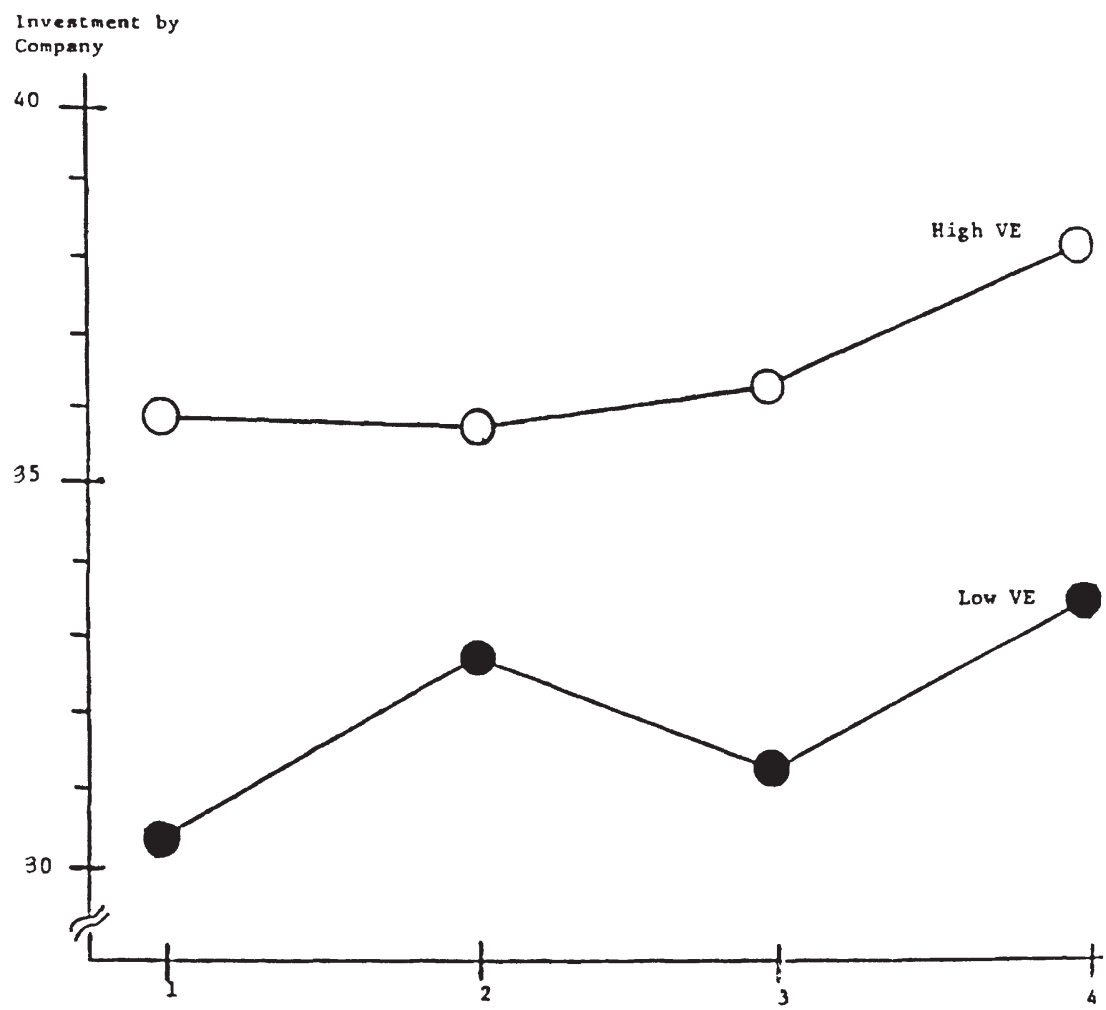

Figure 1. Investment by company.

managers, and (3) status contributed most strongly and in a positive direction to both company and self-investment. In the next step, vertical exchange was entered into the regression equations. As expected, the effect of vertical exchange was positive and significant for both of the dependent variables.

To test the first hypothesis, the unique contributions of vertical exchange to the dependent variables were calculated. The results of this analysis are shown in Table II as the differential coefficient of determination $\left(d=R_{1}^{2}-R_{2}^{2}\right)$. As the table shows, vertical exchange contributed significantly to career investment activities, independent of the effects of the background variables $(d=.261, p<.01$ for company investment; $d=$ $.176, p<.01$ for self-investment). Thus, the unique portion of variance explained by vertical exchange (figures under $d$ ) is $26.1 \%$ for company investment and $17.6 \%$ for self-investment. These findings indicate that, as hypothesized, managers with a higher quality vertical exchange relation- 


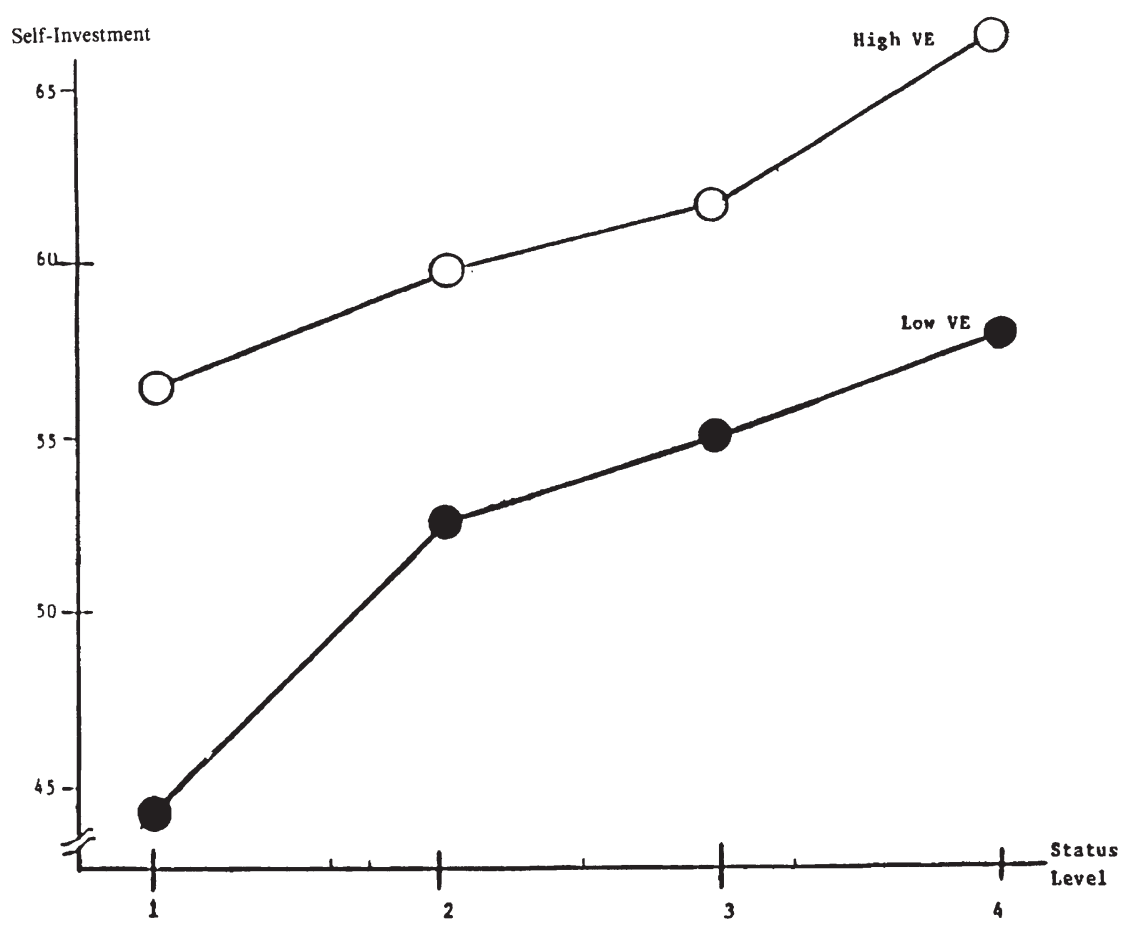

Figure 2. Discretional role development.

ship with supervisors experience more company and self-investment activities than their lower vertical exchange colleagues.

To test the second hypothesis, the specific patterns of effects of vertical exchange across hierarchical level (status) were examined. These relationships are illustrated in Figures 1 and 2. In Figure 1, vertical exchange (high, low) and status (levels 1-4) were examined for their effect on company investment. As the figure shows, high vertical exchange managers received higher amounts of company investment than lower vertical exchange managers across each hierarchical level. Similarly, in Figure 2, high vertical exchange managers were consistently higher on self-investment behaviors, across hierarchical levels, than their lower vertical exchange colleagues. Thus, as hypothesized, the positive contributions of vertical exchange were consistent at each hierarchical level from management trainee to middle manager.

Finally, to clarify the empirical relationships found in the regression analysis, a path analysis was performed. To conduct this path analysis, it was necessary to determine the paths by which the background variables 


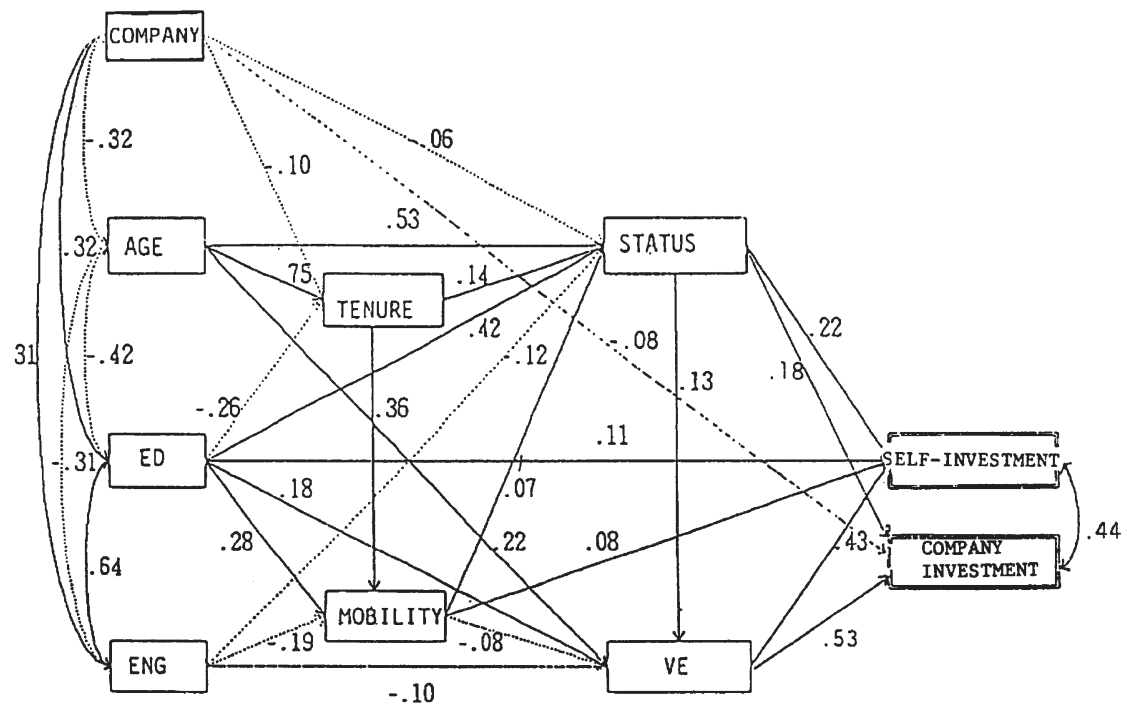

Figure 3. Summary results of path analysis (ED = education, ENG = engineer, and $\mathrm{VE}=$ vertical exchange).

may indirectly influence the career-relevant outcomes. Upon closer examination of the regression results, it appeared that two paths were most likely: one through vertical exchange and another through status. Both of these variables make strong and positive contributions to the dependent variables, in contrast to the other predictor variables which provide mixed results. However, since both variables are quite different from each other, it could be expected that they will provide different paths through which the background variables may influence investment activities. The path through vertical exchange could be expected to be influenced less by background variables, since vertical exchange is a process that emerges on the job based on teamwork between two personalities. In contrast, the path through status would be expected to be influenced more by background variables because of the institution of seniority-based promotion in Japanese organizations. A "pure" seniority-based management progress system would permit incremental career development opportunities only with promotions to higher status positions. In other words, in the second career path, the career opportunities would be closely calibrated to the status of each position in the hierarchy.

Thus, the two paths, one through vertical exchange and the other through status, were subjected to a path analysis using a hierarchical pro- 
cedure (Land, 1969). Summary results of this analysis are presented in Figure 3. As shown in this path diagram, positive and significant paths $(p<.05)$ are indicated by solid lines, and negative and significant paths $(p<.05)$ are indicated by dotted lines. The model analyzed was company, age, education, and engineering contributing to tenure and mobility contributing to status and vertical exchange contributing to company investment and self-investment.

Results presented in Figure 3 clearly show that status received positive contributions from age, education, tenure, and mobility, and negative contributions from company (manufacturing) and engineer (engineering background). This constitutes one path to company investment and self-investment. Following this path, age and education contribute to status in the management hierarchy, which in turn contributes to opportunities for company investment and self-investment activities. A second and much stronger path to company and self-investment is through the vertical exchange relationship with the supervisor. As Figure 3 indicates, quality of vertical exchange is a positive but weak function of the educational level, age, and status, and a negative and weak function of mobility and engineering. Following this path, age, education, and status level contribute to the quality of vertical exchange, which in turn contributes to company and self-investment activities.

In summary, as expected, one clear path to managerial career progress in Japanese organizations is through education and seniority (age and/ or tenure). Another clear path runs through vertical exchange with one's supervisor. To get on this path, no single important background factors were identified, but almost all of them were found to have some influence, either directly or indirectly. As a final note, Figure 3 indicates that the two criterion variables correlate moderately highly $(r=.44)$. Thus, it is possible that self-investment activities may lead to company investment, and company investment may lead to self-investment.

\section{Discussion}

As predicted, vertical exchange was found to contribute positively to hidden investment activities. Moreover, the positive contribution of vertical exchange to career investment was consistent across hierarchical levels. These findings provide support for the generalizability of the hidden investment hypothesis across Japanese corporations. The findings also provide clarification of the effect of vertical exchange upon a manager's career progress which was found in the preceding 13-year investigation (Wakabayashi et al., 1988). Specifically, the positive effect of vertical exchange on career progress which was found in the Japanese Management Progress study appears to be operating through its influence on the ca- 
reer investment activities which the high vertical exchange managers receive. This indicates that vertical exchange influences career progress by allowing the high vertical exchange managers to receive greater amounts of career investment activities than the lower vertical exchange managers, and thus to become better prepared for advancement into higher hierarchical levels in the organization.

In addition to the support for the hypotheses concerning the generalizability of the hidden investment hypothesis across Japanese corporations, the present investigation also made a significant finding concerning the career paths through which Japanese managers may progress. As the results of the path analysis indicate, two separate paths may be taken to achieve career progress in Japanese organizations. One path appears to be the traditional seniority system which is based on age/tenure and education and leads through promotions to career investments. The other is based on the quality of the vertical exchange relationship between managers and their supervisors, and is influenced more by the characteristics of the leader-member relationship than the background variables of the manager. Documentation for the existence of the "hidden face" path which occurs through the vertical exchange relationship provides a significant contribution to the literature in this area, since traditional views of the Japanese management system have been strongly supportive of the seniority system (Yoshino, 1968), without considering the possibility that alternative career paths exist. The present findings suggest that perhaps the view of slow and steady "lock-step" movement up the ladder by the Japanese based on age and seniority is a cultural stereotype, rather than an accurate description of career progress.

The findings of the "hidden face" path are also interesting because of their implications concerning the operations of a "fast track" and a "slow track" in leading Japanese corporations. In particular, it appears that the seniority path is employed mainly to "save face" for the slower developing managers and the hidden face path is used to stimulate the growth and development of the future executives. The relative contributions of status and vertical exchange to company investment (.18 and .53, respectively) and self-investment (.22 and .43, respectively) are taken as support for this speculation. Once again, these findings provide support for the differentiated rather than the lock-step process by which Japanese career progress occurs.

Thus, the present study suggests that more opportunities for investment were provided to those managers operating under high-quality vertical exchanges. These opportunities make it possible for managers with higher quality vertical exchanges to become more involved in self-investment behaviors in their career progress because of the greater trust and support they receive from both their supervisors and the company. This finding has important implications for career progress among Japanese 
managers. Apparently, it is these self-investment activities, in addition to company investment, education, and tenure, that actually contributed to career progress of Japanese managers. Moreover, allowing individual efforts directed toward career enhancement on the job makes upward tournament mobility in Japanese organizations very competitive, in contrast to the more steady lock-step system traditionally described.

\section{Conclusion}

The hidden investment hypothesis derived from the 13-year longitudinal investigation of Japanese management progress was supported in this study of 1075 line managers in five leading Japanese corporations. The findings of strong significant contributions of the quality of the working relationship between a manager and his immediate supervisor to individualized career investments and company investment activities support the generalizability of this hypothesis. Moreover, these overall findings were replicated within each of the five companies and in each of the four levels of management progression. Clearly, the path to the executive suite is enhanced by hidden investment in people's careers by their superiors and themselves at each rank. Finally, we suggest that those who seek the key differences between the leading Japanese and the leading Western management development processes consider how the contributions of hidden investments are harnessed for effective teamwork in each system. For the implications of this for Western leadership development, see Graen (1989).

\section{References}

Abegglen, J. C., \& Stalk, G., Jr. Kaisha: The Japanese corporation. New York: Basic Books, 1985.

Bray, D. W., \& Grant, D. L. The assessment center as the measurement of potential for business management. Psychological Monographs, 1986, 80 (Whole no. 625).

Bray, D. W., Campbell, R. J., \& Grant, D. L. Formative years in business: A long-term ATET study of managerial lives. New York: Wiley, 1974.

Cohen, J., \& Cohen, P. Applied multiple regression/correlation analysis for the behavioral science. Hillsdale, N.J.: Erlbaum, 1975.

Dansereau, F., Graen, G. B., \& Haga, W. J. A vertical dyad linkage approach to leadership within formal organizations. Organizational Behavior and Human Performance, 1975, 13, 46-78.

Graen, G. B. Role making processes within complex organizations. In M. D. Dunnette (Ed.), Handbook of industrial and organizational psychology. Chicago: Rand McNally Publishing, 1976, pp. 1201-1245. 
Graen, G. B. Unwritten rules for your career: 15 secrets for fast-track success. New York: Wiley, 1989.

Graen, G., \& Cashman, J. A role-making model of leadership in formal organizations: A developmental approach. In J. G. Hunt and L. L. Larson (Eds.), Leadership frontiers. Kent, Ohio: Kent State University Press, 1975, pp. 143-165.

Graen, G. B., \& Scandura, T. Toward a psychology of dyadic organizing. In L. L. Cummings and B. Staw (Eds.), Research in organizational behavior. Greenwich, Connecticut: JAI Press, 1987, pp. 175-208.

Graen, G. B., \& Wakabayashi, M. Adapting Japanese management development techniques to their transplants in the United States: Focusing on manufacturing. In V. Pucik (Ed.), Internationalization of the Japanese firm. Ann Arbor, Michigan: University of Michigan Press, 1989.

Graen G. B., Wakabayashi, M., Graen, M. R., \& Graen, M. G. International generalizability of American hypotheses about Japanese management progress: A strong inference investigation. The Leadership Quarterly, 1990, 1, 1-23.

Johnson, C. The export of Japanese-style management to America. In V. Pucik (Ed.), Internationalization of the Japanese firm. Ann Arbor, Michigan: University of Michigan Press, 1989.

Katerberg, R., \& Hom, P. Effects of within-group and between-groups variation in leadership. Journal of Applied Psychology, 1981, 66, 218-223.

Land, K. C. Principles of path analysis. In E. T. Borgatta (Ed.), Sociological methodology. San Francisco, California: Jossey-Bass, 1969.

Liden, R., \& Graen, G. Generalizability of the vertical dyad linkage model of leadership. Academy of Management Journal, 1980, 23, 451-465.

Ouchi, W. G., \& Johnson, J. B. Types of organizational control and their relationship to emotional well-being. Administrative Science Quarterly, 1979, 23, 293-317.

Porter, L. W., Crampton, W., \& Smith, F. J. Organizational commitment and managerial turnover: A longitudinal study. Organizational Behavior and Human Performance, 1976, 15, 87-98.

Takagi, H. The Flow of Japanese management. Ann Arbor: UMI Research Press, 1985.

Wakabayashi, M. Management career progress in a Japanese organization. Ann Arbor: UMI Research Press, 1980.

Wakabayashi, M., \& Graen, G. B. The Japanese career progress study: A 7-year follow-up. Journal of Applied Psychology, 1984, 69, 603-614.

Wakabayashi, M., \& Graen, G. B. Human resource development of Japanese managers: Leadership and career investment. In K. Rowland and G. Ferris (Eds.), International human resources management. Greenwich, Connecticut: JAI Press, 1988.

Wakabayashi, M., Minami, T., Hashimoto, M., Sano, K., Graen, G., \& Novak, M. Managerial career development: Japanese style. International Journal of Intercultural Relations, 1980, 4, 391 -420.

Wakabayashi, M., Graen, G. B., Graen, M. R., \& Graen, M. G. Japanese management progress: mobility into middle management. Journal of Applied Psychology, 1988, 73, 217-227.

Yoshino, M. Japan's managerial system. Cambridge: MIT Press, 1968.

Zalesny, M., \& Graen, G. Exchange theory in leadership research. In G. Reber (Ed.), Encyclopedia of leadership. Linz: Linz University Press, 1986. 


\section{Authors}

Mitsuru Wakabayashi is a Professor in the Department of Educational Psychology at the University of Nagoya, Japan. He received his $\mathrm{PhD}$ degree in Labor and Industrial Relations from the University of Illinois at Urbana-Champaign and recently held a Fulbright Fellowship at the University of Cincinnati. His current research interests are focused on the progress of Japanese managers transferred by their companies to North America and comparative human resource management programs and practices. He is editor of the Japanese Administrative Sciences Journal and a charter member of the Association of Japanese Business Studies.

George B. Graen is Professor of Organizational Behavior and Director of the Center for the Enhancement of International Competitiveness at the University of Cincinnati. After receiving his PhD degree in Industrial/Organizational Psychology from the University of Minnesota, he began his academic career at the University of Illinois at Urbana-Champaign. In 1972, as a Distinguished Exchange Professor, he spent a year at Keio University in Japan studying Japanese management practices. The research begun there continues to the present time. Professor Graen has published over 100 journal articles, technical reports, book chapters, and books. He is a Fellow of the American Psychological Association and a member of the Society of Organizational Behavior.

Mary Uhl-Bien is a PhD candidate in Organizational Behavior at the University of Cincinnati. Her current research interests include international management, leadership, teamwork processes, and multidisciplinary team functioning. 